\title{
İlaç-İlaç Etkileşimleri Konusunda Farkındalık
}

\author{
Mehmet Emin BÜYÜKOKUROĞLU ${ }^{1}$, Pelin TANYERİ ${ }^{1}$, Rümeysa KELES ${ }^{1}$
}

\begin{abstract}
$\ddot{O} z$
Çoklu ilaç tedavileri kaçınılmaz olarak ilaç-ilaç etkileşmelerine neden olabilmektedir. $\mathrm{Bu}$ durum ciddi sağlık sorunlarına yol açmakta ve hastaların zarar görmesi durumunda malpraktis açısından da hekimleri sorumlu hale getirmektedir. Çoklu ilaç tedavisi rejimleri her zaman için olumsuz etkileșme riskini taşırlar. Çoklu ilaç tedavisi rejimleri hem hekimleri bunaltmakta ve hem de olumsuz etkileşme riski taşımaları nedeniyle, bu tedavi rejimlerinin güvenliliğini sorgulanır hale getirmektedir. Bu yazıda, ilaç-ilaç etkileşmeleri hakkında genel bilgiler yanında önemli etkileșme örnekleri verilecektir. Yine makalemizde ilaç-ilaç etkileşmelerinin önlenmesine yönelik bazı öneriler yer alacaktır.
\end{abstract}

Anahtar Kelimeler: Çoklu ilaç tedavisi, ilaç-ilaç etkileşmeleri, veri tabanı
Yayın Bilgisi

Gönderi Tarihi: 25.04.2019

Kabul Tarihi: 13.03.2019

Online Yayın Tarihi: 30.06.2019

DOI: 10.26453/otjhs.557973

Sorumlu Yazar

Pelin Tanyeri, Sakarya Üniversitesi, Tıp Fakültesi, Tibbi Farmakoloji Anabilim Dalı, Sakarya - Türkiye.

Tel: $++(90) 5305125590$

Fax: $+(90) 2642552102$

E-posta: pelintanyeri@yahoo.com

\section{Awareness on Drug-Drug Interactions}

\section{Mehmet Emin BÜYÜKOKUROĞLU ${ }^{1}, \underline{\text { Pelin TANYERİ }}^{1}{ }^{1}$ Rümeysa KELEȘ $^{1}$}

\begin{abstract}
Multi-drug therapies inevitably cause drug-drug interactions. This situation leads to serious health problems and makes the doctors responsible for malpractice in case of harm to patients. Multi-drug therapies have the risk of negative interactions. Multi-drug therapies are questioning their safety because of the risk of negative interaction and the stress on physicians. In this review, we are giving general information about drug-drug interactions as well as examples of important interactions. Also, some suggestions will be given to prevent drug-drug interactions.
\end{abstract}

Keywords: Multiple drug therapy, drug-drug interactions, database
Article Info

Received: 25.04.2019

Accepted: 13.03.2019

Online Published: 30.06 .2019

DOI: 10.26453/otjhs.557973

Corresponding Author

Pelin Tanyeri, Sakarya Üniversitesi, Tıp Fakültesi, Tibbi Farmakoloji Anabilim Dalı, Sakarya - Türkiye.

Tel: + (90) 5305125590

Fax: +(90) 2642552102

E-posta: pelintanyeri@yahoo.com

${ }^{1}$ Sakarya Üniversitesi, Tıp Fakültesi, Tıbbi Farmakoloji Anabilim Dalı, Sakarya, Türkiye.

\section{GíRiş}

Çoklu ilaç tedavileri bazen etkileşmeler nedeniyle ciddi sağlı sorunlarına neden olurken, bazen de etkileşmeye bağlı olarak ilaçlardan bir tanesinin etkisinin ortadan kalkması nedeniyle o ilacın tedavi edeceği hastalığın tedavisiz kalmasına neden olabilmektedir. Terapötik indeksi düşük olan ilaçlar ciddi ilaç-ilaç etkileşimleri açısından daha fazla risk oluşturmaktadır. İlaç-ilaç etkileşimleri nedeniyle hastaların zarar görmesi, 
tıbbi hata açısından da hekimleri sorumlu hale getirmektedir.

Her yıl çok sayıdaki ilacın kullanıma girmesi nedeniyle hekimler yeni keşfedilen ilaçların etkileşimleri hakkında sıklıkla bilgilendirilmektedirler. Ancak, ilaç etkileşimlerini bilmek hekimler için önemli bir husus olmakla beraber, tüm muhtemel etkileşimleri hatırda tutabilmek çoğu kez mümkün olamamaktadır. Çoklu ilaç tedavisi rejimleri her zaman için olumsuz etkileşme riskini taşırlar. Çoklu ilaç tedavisi rejimleri hem hekimleri bunaltmakta ve hem de olumsuz etkileşme riski taşımaları nedeniyle, bu tedavi rejimlerinin güvenliliğini sorgulanır hale getirmektedir.

$\mathrm{Bu}$ yazımızda, ilaç-ilaç etkileşmeleri hakkında genel bilgiler yanında önemli etkileşme örnekleri verilecektir. Yine ilaç etkileşmelerini önlemeye yönelik birtakım öneriler içermektedir.

\section{İLAÇ-İLAÇ ETKILLEŞIMİ NEDİR?}

İki ilaç bir arada kullanıldığında, kullanılan ilaçlardan birisinin farmakolojik etkisinin diğeri tarafından değiştirilmesi sonucunda ortaya çıkan durum "ilaç-ilaç etkileşmesi” olarak tanımlanmaktadır. İlaç etkileşmelerinin yaygın olmasının en önemli nedeni aynı anda çoklu ilaç kullanımıdır (polifarmasi). Bilindiği gibi ilaçların birbiri ile etkileşimleri farmasötik, farmakokinetik veya farmakodinamik düzeylerde olabilmektedir. ${ }^{1,2}$ Bunlar aşağıda özetlenmiştir.

A- Farmasötik Geçimsizlik: Parenteral tedavi uygulamalarında hastaya çok sayıda enjeksiyon yapmamak amaciyla ilaç çözeltileri birbirleriyle karıştırılabilmektedir. Ancak bu yöntem ilaçlarla ilgili geçimsizliklerin ortaya çıkmasına neden olmaktadır. Geçimsizlik, ilaçların vücuda girmeden önce (in vitro ortamda) ortaya çıkan, aynı infüzyon sıvısı veya enjektör içinde gerçekleşen ve fiziksel veya kimyasal reaksiyonlar sonucu oluşan etkileşmelere denilmektedir. Geçimsizlikler partikül ve çökelti oluşması, renk değişikliği, gaz çıkışı veya bulanıklıklar şeklinde kendisini gösterir. Geçimsizliği olan ilaçlar birlikte kullanılacaklar ise, ayrı injektörler kullanılmalı; infüzyon şeklinde verilecekler ise infüzyon setinin önceki ilaçtan tamamen arınmasından sonra verilmelidir. Yine, parenteral solüsyonların hazırlanmasında kullanılan maddelerin de ilaçlarla geçimsizliği söz konusu olabilir. Bazı geçimsizlik örnekleri tablo-1'de verilmiş olup, çeşitli sağlık kuruluşları tarafından "İlaç Geçimsizliği Listeleri” hazırlanmıştır. ${ }^{2}$

\section{B- Farmakokinetik İlaç-İlaç Etkileşimleri:}

Farmakokinetik düzeyde etkileşimler absorbsiyon, dağılım, metabolizma ve itrah düzeyinde olmak üzere dört farklı etkileşme şeklini içermektedir. ${ }^{2}$ 


\section{1-Absorbsiyon Düzeyinde Etkileşim:}

Bir ilaç diğer bir ilacın uygulama yerinden absorbsiyon (emilim) hızını ve/veya derecesini, çeşitli mekanizmalarla etkiliyor ise buna "absorbsiyon düzeyinde etkileşim" denilmektedir. $^{2}$ Ör: Mide yada barsak lümeninde bir ilaç diğer ilacı bağlayıp, onunla kompleks oluşturarak emilimini yavaşlatabilir. Kolestiramin, kolestipol gibi ilaçlar barsaktan kolesterol emilimini engelleyerek hipolipidemik etki eden ilaçlardandır. Bu etkilerinin yanında varfarin ve digoksin gibi diğer bazı ilaçları da bağlayıp absorbsiyonunu azaltır ve terapötik etkinliklerini azaltır. $\mathrm{Bu}$ durum zehirlenmelerin tedavisinde fayda sağlar. Oral yoldan verilen aktif karbon barsak kanalındaki ilaçların veya enterohepatik sirkülasyona uğrayan ilaçların emilimini engelleyerek dışkı ile atılımını sağladığı için bu ilaçların biyoyararlanımını azaltır. ${ }^{3}$

Diğer bazı ilaçlar mide motilitesini etkileyerek çeşitli ilaçların biyoyararlanımını etkileyebilir. Magnezyumlu antasidler, proton pompa inhibitörleri ve $\mathrm{H} 2$ reseptör blokörleri gibi ilaçlar ise barsak hareketlerini hızlandırarak çeşitli ilaçların barsak yüzeyine temas süresini azaltır ve buna ikincil olarak emilimini azaltır. Ayrıca prokinetik ilaçlar olan metoklopramid ve domperidon mide boşalma hızını arttırarak parasetamol ve siklosporinin absorbsiyon hızının artmasına neden olur.
Antineoplastik tedavi sirasinda kullanılan sitotoksik ilaçlar ve gut tedavisinde kullanılan kolşisin, bağırsak mukozasında hasar meydana getirdiği için dolayısı ile temas yüzeyini azalttığı için ilaçların emilimini azaltabilir. Bağırsaklarda katyonik bileşikler (Fe, $\mathrm{Ca}, \mathrm{Zn})$ iyonize olan ilaçlarla kompleksler oluşturarak emilimini engeller. Örneğin, digoksin katyon içeren ilaçlarla birlikte verildiğinde kompleks oluşup emilimi zorlaşır ve terapötik etkinliği azalır. Tetrasiklinler ve kinolon grubu ilaçlarla 2 ve 3 değerli metal bileşiklerinin şelasyon yapmaları da bu duruma bir örnektir. ${ }^{2}$

P-glikoprotein klinik açıdan çok önemli olan transmembran taşıyıcı proteinlerden bir tanesidir. Normal dokularda olduğu gibi tümör hücrelerinde de bulunmaktadır. P-glikoprotein ksenobiyotiklerin hücre dışına atılmasında rolü olan ATP-bağımlı efluks proteinidir. Çok sayıdaki molekül bu proteinin substratı olup, bunların emilmesi veya atılmasında rol oynamaktadır. P-glikoproteinin etkinliğinin inhibe edilebildiği veya indüklenebildiği, polimorfizme bağlı olarak değișebildiği belirtilmiştir. $^{4} \quad \mathrm{Bu}$ durum ilaçların biyoyararlanımlarının artması veya azalmasına neden olmakta ve farmakokinetik niteliklerinde değişikliğe yol açmaktadır. Örnek olarak, kalpdamar sistemde etkili olan ilaçlardan amiodaron güçlü P-glikoprotein inhibitörü olup, digoksinin ince barsaklardan veya böbrek tubuluslarından 
efluksunun inhibe olduğu; serum digoksin düzeyinin arttığı gösterilmiştir. ${ }^{5}$

\section{2-Dağılım Düzeyinde Etkileșim:}

Plazma proteinlerine ileri derecede bağlanan (varfarin ve fenitoin gibi) iki ilacın bağlanma noktaları için birbiri ile yarışması sonucu bir ilacın diğerinin etkisini değiştirmesi, dağglım düzeyinde etkileşme olarak tanımlanmaktadır. $\mathrm{Bu}$ etkileşim ilacın plazma proteinlerinden ayrılıp serbest fraksiyonunu arttırdığı için etkinin artması ile sonuçlanır. Ör: plazma proteinlerine yüksek oranda bağlanan bir antikoagülan ilaç olan varfarin ile aspirin beraber kullanıldığında, kısa süreli de olsa varfarinin serbest fraksiyonu artacağından etkilerinde de artma meydana getirerek protrombin zamanı ve uluslararası düzeltme oranına (PT/INR) düzeylerini etkileyebilir.6 Salisilat ve fenilbutazon gibi plazma proteinine fazla bağlanan ilaçlar ile birlikte fenitoin alımı, fenitoinin serbest fraksiyonunu arttırarak etkisinde de artma meydana getirebilir. ${ }^{2}$

Diğer yandan, P-glikoproteinin aynı zamanda kan-beyin engelinde de rolü olup çeşitli ilaçların santral sinir sistemine dağılımını etkilemektedir. P-glikoprotein inhibitörleri ilaçların santral sinir sistemine geçişini ve buradaki dağılımını artırırken, P-glikoproteinin indüksiyonu bunu azaltmaktadır. Örnek olarak; P-glikoprotein inhibitörü siklosporin beyindeki karvedilol konsatrasyonunu dört kata kadar artırırken, deksametazon ile morfin birlikte beş gün rsüreyle verildiklerinde beyindeki $\mathrm{P}$ glikoprotein düzeyinin $\operatorname{arttığı~ve~morfinin~}$ antinosiseptif etkisinin azaldığı gösterilmiştir. ${ }^{7}$

\section{3-Metabolizma Düzeyinde Etkileşim:}

İki farklı ilacın birlikte kullanımı sonucu ilaçlardan birinin karaciğerde metabolizmadan sorumlu olan mikrozomal enzimlerinde (Sitokrom P450) inhibisyon veya indüksiyon yapmasına bağlı diğer ilacın etkisinde azalma veya artma meydana getirmesine metabolizma düzeyinde ilaç etkileşimleri denilmektedir. İlaçlar metabolizmalarını indükleyen ilaçlarla birlikte kullanıldıklarında, yıkımları artacağından terapötik etkilerinde azalma, metabolizmalarını inhibe eden ilaçlarla birlikte kullanıldıklarında, yıkımları azalacağından terapötik etkilerinde artma olur. Ör: simetidin, makrolidler, fluorokinolonlar, bitkisel tıbbi ürünler, selektif seratonin gerialım inhibitörleri, azol grubu antifungaller ve diğer bazı ilaçların yaptığı enzim inhibisyonu (CYP1A2, CYP2C9, CYP3A4, CYP2D6), çeşitli ilaçların (varfarin, teofilin, digoksin, fenitoin, siklosporin..) yıkımını azaltabilir ve ilaçların konsantrasyonlarında meydana gelen bu artış yaşamı tehdit eden komplikasyonlar gözlenmesine neden olacaktır. Sitokrom P450 enzim indüksiyonuna örnek vermek gerekirse; rifampin, bazı antiepileptik ilaçlar (Fenitoin, karbamazepin), selektif seratonin gerialım inhibitörleri gibi ilaçlar meydana getirdikleri enzim indüksiyonu ile oral antikoagülanların, 
barbitüratların, oral kontraseptiflerin, siklosporinin, digoksinin ve fenitoinin yıkımını arttırırlar ve etkilerini azaltırlar. ${ }^{8-12}$

\section{4-İtrah Düzeyinde Etkileşim:}

İlaçların itrahında glomerüler filtrasyon, tubuler sekresyon ve bunlara zit olarak tübüler geri emilim mekanizmaları rol oynar. Bazı ilaçlar böbrekten taşıyıcı proteinin kullanıldığı tübüler sekresyon ile itrah edilirler. Aynı taşıyıcı proteini kullanan iki ilaç birlikte kullanılırsa biri taşıyıcı proteine bağlanacağından diğerinin itrahı bozulur ve ilacın vücutta kalış süresi uzar. $\mathrm{Bu}$ yüzden ilacın etki süresi uzar ve buna bağlı olarak toksik etkiler meydana gelebilir. Örneğin; verapamil, itrakanozol, kinidin, amiodaron, klaritromisin, ritonavir gibi ilaçlar böbrekte P-glikoprotein pompasını inhibe ederek digoksinin tübüler salgılanmasını azaltır ve itrahını engeller. $\mathrm{Bu}$ durum digoksinin plazma düzeylerinde artmaya ve toksisiteye yol açabilir. $^{2}$

Bazı ilaçlar glomerüler filtrasyon ve tübüler geri emilim mekanizmalarını etkileyerek diğer ilaçların itrahını etkileyebilir. Örneğin (kaptopril, enalapril, lisinopril ve imidapril gibi) ACE inhibitörleri glomerüler filtrasyon basıncını azaltarak lityumun tübüler geri emilimini ve böylelikle, lityum konsantrasyonunu artırabilir. ${ }^{13}$

İlaçlar asidik veya bazik olmalarına göre itrah sırasında farklılıklar gösterebilir. Pasif difüzyona uygun bir membran ile ayrılmış iki kompartman arasında $\mathrm{pH}$ farkı varsa, asidik ilaçlar bazik olan tarafta, bazik ilaçlar ise asidik olan tarafta iyonize olacağından (iyon tuzağı) membranı geçemeyecek ve daha yüksek konsantrasyonda toplanma eğilimi gösterecektir. $\mathrm{Bu}$ durum, ilacın itrahını arttıracağından zehirlenme gibi klinik durumlarda kullanılabilir. Örneğin zayıf bazik ilaç olan fenitoin, teofilinin itrahını idrarı asitleştirilerek; zayıf asidik ilaç olan varfarinin ise itrahını idrarı bazikleștirilerek artırılabilir. ${ }^{2}$

\section{C- Farmakodinamik İlaç-İlaç Etkileşimleri:} Bir ilaç diğerinin etkisini ilacın plazmadaki konsantrasyonunu değiştirmeden; reseptör düzeyinde aynı veya farklı reseptörleri kullanıp zıt ya da aynı yönde etki yaparak veya onunla kimyasal olarak etkileşerek değiştiriyorsa buna farmakodinamik etkileşim denilmektedir. ${ }^{1} \mathrm{Bu}$ etkileşmeler değişme yönüne göre antagonizma (etkinin azaltılması) veya sinerjizma (etkinin arttırılması) şeklinde olur. İki ilacın birlikte gösterdikleri etki ayrı ayrı oluşturdukları etkinin toplamı kadar ise buna aditif etkileşme, toplamindan fazlaysa potansiyalizasyonm (supraaditif etkileşme) denir. Örnek vermek gerekirse; Trisiklik antidepresanlar ile lityumun birlikte kullanımında ortaya çıkan antidepresan etki artışı sinerjik etkiye bir örnektir. ${ }^{14}$ Teofilin, efedrin veya diğer sempatomimetik ilaçlarla birlikte verildiği zaman toksik düzeyde 
sinerjizma meydana getirip sempatik etkide artış yapabilir. Ginkgo biloba ekstreleri ile antikoagülan (varfarin) veya antiplatelet (tiklopidin) kullanımı sırasında ekstrelerin Platelet Aktive Edici Faktör'ü inhibe etmesine bağlı olarak etkinin potansiyalizasyonundan dolayı kontrol edilemeyen kanamalar görülebilir.

Reçete bilgileri çoğu ilaç için, potansiyel ilaç etkileşimlerinin bir listesini içerir. Listelenen etkileşimlerin birçoğu nadir gözlemlenebilir, minör etkileşimler olabilir veya sadece belirli koşullar altında meydana gelebilir. Ancak, ilacın etkisinde önemli değişikliklere yol açan ilaç etkileşimleri ciddi ve dikkat edilmesi gereken bir durumdur. Birçok ilaç etkileşime girme ve ciddi sağlık sorunlarına neden olma potansiyeli nedeniyle piyasadan çekilmiştir. Bilinen bir etkileşim her bireyde gözlemlenmeyebilir çünkü bir etkileşimin meydana gelme olasılığını etkileyen çeşitli faktörler vardır. Bu faktörler; genler, fizyoloji, yaş, yaşam tarzı (diyet, egzersiz), altta yatan hastalıklar, ilaç dozları, kombine tedavinin süresi ve iki ilacın alınma/uygulama zamanı (Eğer iki ilaç farklı zamanlarda alınırsa bazen etkileşimler önlenebilir) gibi bireyler arasındaki farklılıkları içerir. $^{15}$ En çok rastlanan ilaç etkileşimleri tablo2’de verilmiştir. ${ }^{16}$

\section{En ciddi ilaç-ilaç etkileşimler}

FDA' ya göre, ilaç kullanımı hastada aşağıdaki durumlara sebep olursa ciddi bir yan etki tanımı yapmak mümkün olur.

• Ölüm

- Hayatı tehdit eden durum

- Hastanede yatış

- Özürlülük — hastanın bedensel işlevi / yapısı, fiziksel aktiviteleri ya da yaşam kalitesinde önemli, kalıcı, bozulma, hasar durumunun olması

- Konjenital anomali

- Sürekli bozulmayı veya hasarı önlemek için müdahale gerektiren durumlar

En ciddi ilaç-ilaç etkileşimine örnekler tablo-3'te verilmiştir. ${ }^{15}$ En tehlikeli ilaçilaç etkileşimleri ise tablo-4'te gösterilmiștir.

\section{İlaç-İlaç Etkileşimlerinde Farkındalık ve Etkileşmelerin Önlenmesi}

Burada hem hastalar ve hem de sağlik profesyonellerinin sorumluluğu vardır. Hastalara ilaç-ilaç etkileşimlerinin önlenmesinde büyük görev düşmektedir. Öncelikle hastaların kullanmış oldukları ilaçlarla ilgili yaşadıkları olumsuzlukları hekimlerine bildirmeleri çok önemlidir. Hastaların, reçeteli veya reçetesiz ilaçlar, vitaminler, bitkisel takviyeler gibi ürünler dahil, kullanıyor oldukları tüm ilaçları hekimlerine söylemeleri gerekmektedir. 
Böylece hekimlerin uygun ilaçları reçete edebilmesi sağlanmış olur. Yine, hastalar uygun web siteleri ve veri tabanlarını kullanarak ilaç etkileşmeleri hakkında bilgi sahibi olabilirler. Hekimler, hastalarına ilaç reçete etmeden önce, yaş, eğitim ve bilgi düzeylerine uygun şekilde çok iyi bir sorgulama yapmaları önemlidir. Her yıl çok sayıdaki ilacın kullanıma girmesi nedeniyle, sağlık profesyonellerinin potansiyel ilaç etkileşimlerini önlemek için sadece belleğe güvenmeleri artık pratik değildir. $\mathrm{Bu}$ nedenle sağlı profesyonellerinin uygun web siteleri ve veri tabanları kullanmaları gerekir. Sağlık personeline ve topluma yönelik bazı web siteleri ve veri tabanları tablo-5 'te verilmiştir. ${ }^{19-21}$

\section{REFERANSLAR}

1. Aktay G, Hamit Hancı İ, Balseven A. İlaç Etkileşimleri ve Hekim Sorumluluğu. Sürekli Tıp Eğitimi Dergisi. 2003;12(7):261-4.

2. Kayaalp O. Rasyonel Tedavi Yönünden Tibbi Farmakoloji. 12. Baskı. Ankara, Pelikan Yayıncılık; 2009.

3. Çopur MS, Oto A. Dijital Glikozidleri ve Diğer İlaçlar Arasındaki Etkileşim. Türkiye Klinikleri. 1988;8(3):201-7.

4. Iş1l GG，Gül E，K. Oğuz K. Pglikoprotein ve Tedaviye Dirençteki
Rolü. Psikiyatride Güncel Yaklaşımlar. 2016;8(1):19-31.

5. Jeffrey DW, Laura TG, Jeanne M, Robert PG. The P-Glycoprotein Transport System and Cardiovascular Drugs. J Am Coll Cardiol. 2013;61(25):2495-5026.

6. Eroğlu SE, Altınok DA, Özpolat, et al. The investigation of the relation between INR levels and risk of complication in patients with a history of warfarin use. Marmara Med J. 2012;25:138-42.

7. Eyal S, Hsiao P, Unadkat JD. Drug interactions at the blood-brain barrier: Fact or fantasy? Pharmacol Ther. 2009;123(1):80-104.

8. Brunton LL, Lazo JS, Parker KL. Goodman \& Gilman Tedavinin Farmakolojik Temeli. 2. Bask1. İstanbul, Nobel T1p Kitapevleri; 2009. 9. Aşçı A, Baydar T, Şahin G. Evaluation Of Usage Of Herbal Preparation And Drug Interactions In Elderly People From Toxicological Aspect. Turkish Journal of Geriatrics. 2007;10(4):20314.

10. Yamantürk P. Antibiyotik-Diğer İlaç\Besin Etkileşimi. Ankem Dergisi. 2001;15(3):443-6.

11. Savaş H, Coşkun A, Arkonaç O. Yeni Bir Antidepresan: Sertralin. Düşünen Adam Düşünen Adam Psikiyatri ve 
Nörolojik Bilimler Dergisi. 1994;7(3):46-8.

12. Yüksel N. Duloksetin: Farmakolojisi. Klinik Psikiyatri. 2009;12(1):3-8.

13. Alkan F, Altınbaş K. Perindopril Kullanımı Sonrasında Serum Lityum Düzeyinde Yükselme: Bir Olgu Bildirimi. Düşünen Adam Psikiyatri ve Nörolojik Bilimler Dergisi. 2012;25(1):70-3.

14. Kırlı S. Sitokrom P450 ve Antidepresan İlaç Etkileşimleri. Düşünen Adam Psikiyatri ve Nörolojik Bilimler Dergisi. 1999;12(1):2-50.

15. Ansari J. Drug Interaction and Pharmacist. Young Pharm. 2010;2(3):326-331.

16. Sağlık Bakanlığı Kodu: S.İY.LS.09. https://dosyaism.saglik.gov.tr/Eklenti/ 46949,iyt104- ilac-ilac-ve-besin-ilacetkilesimleri-ile-ilgili-talimat31052018 pdf.pdf?0 . 2016.
17. Erciyes Üniversitesi Diş Hekimliği Fakültesi. Döküman No: SIYY.LS.02. http://dent.erciyes.edu.tr/Dosyalar/Kal iteYonetimBirimi/SIY_LS_02_Ilac_E tkilesim_Gecimsizlik_Listesi.pdf. 2018.

18. Emine G, Hakan E. Quinolones. İç Hastalıkları Dergisi. 2014;(21):69-85. 19. Doğan H.D., Çalışkan K. Why Rational Drug Management In An Elderly Individual?, International Health Administration and Education (Sanitas Magisterium). 2019;5(2), 6070.

20. Songül Ü, Gönül Ş, Terken B. Kanser Tedavisinde Olası İlaç Etkileşmelerinin Toksikolojik Sonuçları. Turkiye Klinikleri J Pharm Sci. 2012;(2):111-23.

21. Şule K. Bitkisel Ürünlerle Tedavilerde İlaç Etkileşmeleri. Dokuz Eylül Üniversitesi Tıp fakültesi dergisi. 2017;31(1):49-50. 
Tablo 1. Farmasötik geçimsizlik bulunan bazı ilaçlar.

\begin{tabular}{|l|l|}
\hline Difenhidramin & Deksametazon, Metilprednizolon, Sefazolin \\
\hline Prometazin & Deksametazon, Metilprednizolon, Klindamisin \\
\hline Proklorperazin & Deksametazon, Klindamisin, Sefazolin \\
\hline Aminoglikozidler & Penisilinler, Sefalosporinler \\
\hline Amfoterisin B & Serum fizyolojik \\
\hline Fenitoin & Dekstroz solüsyonu, lorazepam (ilaçlar etkisiz hale gelir) \\
\hline $\begin{array}{l}\text { Diazepam ve diğer } \\
\text { benzodiazepinler }\end{array}$ & Hiçbir ilaçla karıştırılmamalıdır. \\
\hline
\end{tabular}


Tablo 2. En çok rastlanan ilaç-ilaç etkileşimlerinden bazı örnekler. ${ }^{16}$

\begin{tabular}{|c|c|}
\hline Alkol-Barbitüratlar & $\begin{array}{l}\text { Barbitüratlarla birlikte alkol alınması SSS'inde depresyonun artması sonucu koma ve ölüme } \\
\text { neden olabilir. }\end{array}$ \\
\hline Aminoglikozit-Heparin & $\begin{array}{l}\text { Birlikte enjekte edilmemelidir. Aminoglikozitlerin dozajında heparinli tüpler } \\
\text { kullanılmamalıdır. }\end{array}$ \\
\hline $\begin{array}{l}\text { Aminoglikozitler-B12 vit,Kolşisin, } \\
\text { Metotreksat,5FU }\end{array}$ & $\begin{array}{l}\text { Aminoglikozitler, B12 vit, Kolşisin, Metotreksat, 5FU ilaçlarının absorbsiyonunda azalma } \\
\text { görülür. }\end{array}$ \\
\hline Anestezik İlaçlar- Rifampisin & $\begin{array}{l}\text { Rifampisin, hepatotoksik potansiyeli olan anestezik ilaçlarla (halotan) kullanılırsa karaciğer } \\
\text { bozukluklarına yol açabilir. }\end{array}$ \\
\hline Antasidler- Oral Kontraseptifler & Antasid ilaçların oral kontraseptiflerin etkinliğini azalttığı bildirilmiştir. \\
\hline Antibiyotikler- Hidrokortizon & $\begin{array}{l}\text { Hidrokortizon, aynı infüzyon şişesinde tetrasiklinler, kanamisin ve kloramfenikolle çökme } \\
\text { yapar. }\end{array}$ \\
\hline $\begin{array}{l}\text { Beta adrenerjik } \\
\text { reseptör blokörleri - } \\
\text { Antidiabetikler }\end{array}$ & Beta adrenerjik reseptör blokörü ilaçlar, insulin ve oral antidiabetiklerin etkilerini artırır. \\
\hline Antiepileptik ilaçlar-Metadon & $\begin{array}{l}\text { Metadon, karbamazepin'in serum düzeyini arttırarak toksik etkilerinin ortaya çıkmasına neden } \\
\text { olabilir. }\end{array}$ \\
\hline $\begin{array}{l}\text { Antiepileptik ilaçlar-Oral } \\
\text { Kontraseptifler }\end{array}$ & $\begin{array}{l}\text { Hidantoin, pirimidon, barbitüratlar, karbamazepin gibi antiepileptik ilaçlar, oral kontraseptif alan } \\
\text { kadınlarda ara kanamalarına ve gebeliğe neden olabilirler. }\end{array}$ \\
\hline Antihistaminikler-barbitüratlar & $\begin{array}{l}\text { Antihistaminik ilaçların ve barbitüratların meydana getirdikleri SSS depresyonunda artış } \\
\text { görülür. }\end{array}$ \\
\hline $\begin{array}{l}\text { Antikolinerjikler-Trisiklik } \\
\text { antidepresanlar }\end{array}$ & $\begin{array}{l}\text { Trisiklik antidepresanlarla birlikte antikolinerjik ilaçların kullanılması, aditif } \\
\text { antikolinerjik etkilerin ortaya çıkmasına neden olur. }\end{array}$ \\
\hline $\begin{array}{l}\text { Antihistaminikler-SSS } \\
\text { depresanları }\end{array}$ & SSS üzerine olan depresif etkide artış olabilir. \\
\hline Antineoplastikler- & Kortikosteroidler, metotreksatın toksisitesini arttırabilir. \\
\hline Antitüberkiloz ilaçlar- alkol & $\begin{array}{l}\text { İsoniazid ile birlikte alkol alındığında izoniazidin biotransformasyonu hızlanabilir. Ayrıca alkole } \\
\text { olan tolarans azalır. }\end{array}$ \\
\hline Asetazolamid-Amfetamin & Asetazolamid amfetaminin etkisinin arttırır. \\
\hline Asetazolamid-Aspirin & Birlikte kullanıldığında şiddetli asidoz oluşabilir. \\
\hline Asetazolamid-Barbitüratlar & Asetazolamid, Barbitüratların uyku süresinde artma görülür. \\
\hline $\begin{array}{l}\text { Asetazolamid-Trisiklik } \\
\text { antidepresan }\end{array}$ & $\begin{array}{l}\text { Kortikosteroid Asetazolamid, Trisiklik antidepresanların SSS üzerine olan etkileri } \\
\text { şiddetlenir. }\end{array}$ \\
\hline Barbütüratlar- SSS depresanları & Depresif etkide artış görülür. \\
\hline Barbütüratlar-Reserpin & Reserpin, barbitüratların SSS 'ini deprese edici etkilerini şiddetlendirir. \\
\hline Barbütüratlar-Propranolol & Propranolol, barbitüratların akut toksisitesini artırır. \\
\hline Beta blokörler-Barbütüratlar & $\begin{array}{l}\text { Deney hayvanlarında (fare) propranolol barbitüratların SSS üzerindeki depresif etkisini } \\
\text { artırır. }\end{array}$ \\
\hline Beta blokörler- adrenalin & $\begin{array}{l}\text { Selektif etkili olmayan beta blokör ilaçlar (propranolol) kullananlara adrenalin verilmesi } \\
\text { kan basıncının artmasına ve brakardiye yol açar. }\end{array}$ \\
\hline Difenoksilat-MAO inhibitörleri & Hipertansif kriz meydana gelebilir. \\
\hline Diklofenak-Lityum karbonat & Diklofenak, lityum kan konsatrasyonunu arttırır. \\
\hline Dipiridamol-Heparin & $\begin{array}{l}\text { Dipiridamol trombositlerin adhesyonunu inhibe ettiğinden heparinize hastalarda kanama } \\
\text { riskini artırabilir. }\end{array}$ \\
\hline Disopiramid- Antiaritmikler & $\begin{array}{l}\text { Antiaritmik bir ilaç olan disopiramid'in antikolinerjik etkileride olduğundan aditif bir } \\
\text { etkileşme söz konusudur. }\end{array}$ \\
\hline Dopamin-MAO inhibitörleri & Dopamin-MAO inhibitörlerinin toksik etkiler ortaya çıkabilir. \\
\hline Eritromisin-Glukokortikoidler & $\begin{array}{l}\text { Eritromisin glukokortikoidlerin eliminasyonunu yavaşlatarak kan } \\
\text { konsantrasyonunu yükseltebilir. }\end{array}$ \\
\hline Eritromisin-Teofilin & Eritromisin teofilinin toksik etkilerini arttırır. \\
\hline Fenitoin-Barbitürat & Barbitüratlar fenitoin'in serum düzeyini değiştirebilirler. \\
\hline
\end{tabular}


Genel Anesteziklerbetamimetikler
Halotan, siklopropan, trikloretilen, kloroform vb. Genel anestezik ilaçlarla anestezi sırasında adrenalin ve diğer betamimetiklerin (i.v.) verilmesi şiddetli kardiyovasküler bozukluklara neden olur.

H2 Blokörleri-Simetidin-B blokör

Heparin-Aspirin

Heparin-Dekstran

İnsilün-Klorpromazin

İnsulin-MAO inhibitörü

İnsulin-Tiroid Hormonu

Kalsiyum-Digitalik

Kalsiyum Antagonistleri- Beta adrenerjik reseptör bloköler

Kaptopril- Beta adrenerjik reseptör bloköler

Kaptoril-Diüretikler

Kemoterapötikler-Oral

Kontraseptifler

Simetidin non selektif beta adrenerjik reseptör blokörlerinin etkilerini güçlendirir.

Antikoagülan etkide önemli artış görülür.

Dekstran, heparinin antikuagülan etkisini arttırır.

Klorpromazin, İnsulin'in etkinliğini azaltarak hiperglisemi oluşturabilir.

MAO inhibitörü insulinin etkinliğini artırıp aşırı hipoglisemiye neden olabilirler.

Triiyodotronin ve levotiroksinin bağlanmasını inhibe ederek hipotroidizme neden olabilir.

Ayrica diyabetlilerde insuline gereksinim artabilir.

Digitaliklerin etkisini şiddetlendirir.

Beta adrenerjik reseptör bloköleri, kalsiyum antagonistlerinin (verapamil, nifedimin) kalp üzerine olan etkilerini artırırlar.

Beta adrenerjik reseptör blokörler, kaptoprilin etkinliğini artırır.

Aditif etkileşme görülür.

Penisilinler, sefaleksin, kloramfenikol, tetrasiklinler, eritromisin, klindamisin, baktrim, nitrofuantoin gibi kemoterapötik ilaçlar ara kanamalara ve oral kontraseptif ilaçların etkinliğinde azalmaya neden olabilirler.

Kinidin-Digoksin

Kinidin-Digital

Kinidin-Tubokürarin

Kinidin-Varfarin

Klonidin-Nitroprusiyat

Kloramfenikol- Sülfonilüre

Kloramfenikol- Oral

antikoagülanlar

Kloramfenikol- Tolbutamid

Kloramfenikol-Barbitüratlar

Klortiazid-Digital

Klortiazid-Lityum karbonat

Klortiyazid-Digital

Kortikosteroidler-Sülfonilüre

Lidokain-Barbitüratlar

Lidokain-Benzodiazepinler

Lidokain-Beta blokörler

MAO İnhibitörleri-barbitürat

MAO İnhibitörleri-Oral

antidiabetik

MAO İnhibitörleri- İnsulin

MAO İnhibitörleri- Metildopa

Metildopa-Lityum karbonat

Metotreksat- Alkol

Metotreksat-Aspirin

Naproksen-Oral antikoagulanlar

Nitritler-Alkol

Oral Antidiabetikler- Androjen

İlaçlar

Oral Antikoagulanlar-Testosteron

Oral Antikoagulanlar- Oral

Kontraseptifler

Oral Antikoagulanlar- Tiroit

Hormonu
Digoksin, kinidinle birlikte kullanılırsa serum düzeyi iki katı artar.

Digitalin serum düzeyi artabilir.

Nöromüsküler blokajda artış görülür.

Varfarin hipoprotrombinemik etkinliği arttırabilir.

Nitroprusiyatın kan basıncının düşürücü etkisi artar.

Sülfonilüre bileşiklerinin etki süresini uzatabilir.

Kloramfenikol oral antikoagülanların (kumarin) etkilerini potansiyelize ederler.

Kloramfenikol tolbutamidin hipoglisemiyan etkisini arttırır.

Kloramfenikol barbitüratların SSS üzerine olan depresif etkilerini arttırır.

Potasyum kaybına neden olan diğer diüretikler gibi klortiazid de digitallerin

kardiotoksisitesini arttırır.

Lityumun nörotoksik ve kardiyotoksik etkilerinde artma olur.

Digitallerin miyokard üzerine olan toksik etkilerini artırırlar.

Sülfonilüre türevlerinin etkisini arttırır.

Solunum depresyonunda artış olabilir.

Lidokainin SSS üzerine olan toksik etkilerinde artış görülür.

Lidokainin biyolojik yarılanma ömründe uzama oluşabilir.

Deneysel olarak MAO İnhibitörleri hayvanlarda barbitüratların etkisini artırır.

Oral antidiabetiklerin etkisini artırır.

İnsulin kullanan hastalara MAO inhibitörleri verilmesi hipoglisemi belirtilerini arttırır.

Fenelzin, isokarboksazid, pargilin ve tranilspromin MAO inhibitörleriyle birlikte metildopa kullanılması anteriyel kan basıncında şiddetli artışa neden olur.

Metildopa, lityum karbonatın serum düzeyini artırarak toksik belirtilerin ortaya çıkmasına yol açar.

Alkol metotreksatın hepatotoksik etkisini artırır.

Aspirin, metotreksatın serum düzeyini artırır.

Kumarin gurubu antikuagülanların etkisi naproksen tarafindan arttırılır.

Nitritler alkolle birlikte alınırsa hipotansif etkileri artar.

Androjen ilaçlar, oral antidiabetiklerin etkisini arttırırlar.

Testosteron ve türevleri oral antikuagülanların etkisini arttırabilir.

Oral kontraseptifler, oral antikoagulanların etkinliğini değiştirebilirler.

Tiroid hormonu içeren türevler, oral antikoagülanların hipoprotrombinemik etkisini arttırır. 
Oral Antikoagulanlar- Aspirin, baktrim, allupurinol,anabolic steroidler, simetidin,

klofibrat,sülfonamidler, o

ksifenbutazon ve tiroid hormonu içeren ilaçlar

Parasetamol-Alkol

Parasetamol-Barbituratlar

Parasetamol-Kodein

Penisilin-Eritromisin

Penisilin-Kontraseptifler

Penisilinler-Aspirin

Propranolol-Oral antidiabetik

Propranolol- İnsulin

Salisilatlar-Alkol

Salisilatlar-Antikoagülanlar

Salisilatlar-Antineoplastikler

Salisilatlar-Hidantoinler

Salisilatlar-Kortikosteroidler

Salisilatlar-Oral antidiabetikler

Salisilatlar-Parasetamol

Salisilatlar-Penisilinler

Sefalosporinler-Aminoglikozitler

ilaçlar

Sefalosporinler-Furosemit

Sempatomimetikler- Trisiklik

antideprasan

Sempatomimetikler- MAO

inhibitörü

Sülfonamidler -Kotrimoksazol

Sülfonamidler-Fenitoin

Sülfonamidler-Metotreksat

Sülfonamidler-Oral

antidiyabetikler

Tetrasiklin-Furosemit

Tetrasiklin-oral antikoagülanlar

Tiazid Diüretikler- lityum

karbonat

Triksiklik Antidepresanlar-Tiroit hormone

Trisiklik Antidepresanlar-

Fenotiyazin

Trisiklik Antidepresanlar-Reserpin

Verapamil-Beta blokerler

Verapamil- digital glikozitler

Verapamil- Vazodilatörler

Verapamil- Lityum

Verapamil- Fenobarbital
Aspirin, baktrim, allupurinol, anabolic steroidler, simetidin, klofibrat, sülfonamidler, oksifenbutazon ve tiroid hormonu içeren ilaçlar oral antikoagülanların etkisini arttırırlar.

Kronik alkolizm, parasetamolun neden olduğu karaciğer nekrozun oluşumunu arttırır.

Barbüratlarla birlikte parasetamol kullanılması hepatotoksik etkinin

şiddetlenmesine yol açabilir.

Kodein, parasetamolun hepatotoksik ve nefrototoksik etkilerini arttırabilir.

Antibakteriyel etkide sinerjizma olur.

Kontraseptif etkinlik azalabilir.

Penisilinin biyolojik yarı ömrü uzar serum düzeyi yükselir.

Oral antidiabetiklerin etkisini artırır.

İnsulinin etkisini arttırır.

Salisilatlar içeren analjezik ilaçlarla (aspirin) birlikte alkol alınması, mide mukozasına iritasyonu artırarak gastrik kanamalara yol açabilir.

Oral antikoagulanlarla ve heparinle birlikte salisilat grubu aneljezikler kullanılırsa

hipoprotrombinemik etkileri artar ve kanamalar oluşabilir.

Salisilatlar (aspirin) metotreksatın serum düzeyini yükselterek toksisitesini arttırabilirler.

Salisilatlar, fenitoinin plazma proteinlerine olan bağlarını çözerek kandaki serbest ve aktif konsantrasyonlarını arttırlar.

Hidrokotizon ve salisilatların (aspirin) birlikte kullanılması mide mukozası üzerinde iritan etkinin sumasyonuna neden olurlar.

Klorpropamid, tolbutamin, asotoheksamit ve tolazamid gibi oral antidiabetiklerle birlikte salisilatlar (aspirin) kullanılırsa hipoglisemik etki şiddetlenebilir.

Salisilatlar parasetamolun hepatotoksik ve nefrotoksik etkilerini arttırırlar.

Salisilatlar, penisilin gurubu antibiyotiklerin serum düzeyini arttırır.

Birlikte kullanılmaları sefalosporinlerin (sefaloridin) nefrotoksisitesini arttırabilir.

Birlikte kullanılmaları sefalosporinlerin (sefaloridin) nefrotoksisitesini arttırabilir.

Trisiklik antideprasan ilaçlar, direkt ve indirekt sempatomi metik ilaçlarla birlikte verilirse onların kardiyovasküler etkilerinde şiddetlemmeye yol açarlar.

MAO inhibitörü kullanan hastalara direkt ve indirekt sempatomimetik ilaçların verilmesi hipertansif krize yol açar.

Sülfonilüre türevi oral antidiabetiklerin etkisini arttırırlar.

Bazı sülfonamdiler (ko-trimoksazol) fenitoinin kan konsantrasyonunu arttırırlar.

Sülfonamidler metotreksatın plazma proteinine olan bağlanmasını çözerek serum metotreksat konsantrasyonunu arttırırlar.

Sülfafenazol, tolbutamit ve klorpropamidin hipoglisemik etkisini arttırır.

Tetrasiklinlerle birlikte furosemid kullanılması nefrotoksik etkinin artmasına yol açar.

Tetrasiklinler, oral antikoagülanların etkilerini potansiyelize ederler.

Klortiazid, bendroflumetiyazid ve hidroflumetiyazid gibi tiazid grubu diüretikler lityum karbonatın nörotoksik ve kardiyotoksik etkilerini artırır.

Tiroid hormonu ve L-triodotronin, trisiklik

antidepresanların etkinliğini arttırır

Fenotiyazinlerle, trisiklik antidepresanlar birlikte kullanılırsa her iki gurup ilacın da serum düzeylerinde artma meydana gelir.

Reserpin ve tirisiklik antidepresanların (imipramin) birlikte kullanılması SSS'nin aşırı uyarımına neden olur.

Beta blokerlerle kalp hızı A-V ileti ve/veya kardiak kontraktilite üzerinde adidif negative etkilere yol açar.

Verapamil, digital glikozitlerin klerensini azaltıp serumdaki seviyelerini yükseltir.

Vazodilatörler, diüretikler ACE inhibitörü kan basıncını düşürme de adidif etki yapar.

Lityum famokinetik ve farmodinamik etkisi vardır.

Fenobarbital verapamilin klerensini azaltabilir. 
Tablo 3. En ciddi ilaç-ilaç etkileşim örnekleri. ${ }^{15}$

\begin{tabular}{|c|c|c|}
\hline Etkilenen ilaç & Etkileyen ilaç & Potansiyel Etki \\
\hline Varfarin & $\begin{array}{l}\text { Siprofloksasin, Klartiromisin, Eritromisin, } \\
\text { Metranidazol, Sulfametaksazol }\end{array}$ & Varfarinin etkisinde artış \\
\hline Varfarin & Asetaminofen & $\begin{array}{l}\text { Kanamada artış, } \\
\text { INR' de artış }\end{array}$ \\
\hline Varfarin & Asetil salisilik asit & $\begin{array}{l}\text { Kanamada artış, } \\
\text { INR' de artış }\end{array}$ \\
\hline Varfarin & NSAİ & $\begin{array}{l}\text { Kanamada artış, } \\
\text { INR' de artış }\end{array}$ \\
\hline Fluorokinolon & $+2 /+3$ değerli katyonlar, Sukralfat & Fluorokinolon absorpsiyonunda azalma \\
\hline Karbamazepin & $\begin{array}{l}\text { Simetidin, Eritromisin, Klaritromisin, } \\
\text { Flukonazol }\end{array}$ & Karbamazepin seviyelerinde artış \\
\hline Fenitoin & $\begin{array}{l}\text { Simetidin, Eritromisin, Klaritromisin, } \\
\text { Flukonazol }\end{array}$ & Fenitoin seviyelerinde artış \\
\hline Fenorbarbital & $\begin{array}{l}\text { Simetidin Eritromisin, Klaritromisin, } \\
\text { Flukonazol }\end{array}$ & Fenobarbital seviyelerinde artış \\
\hline Fenitoin & Rifampin & Fenitoin sevielerinde azalma \\
\hline Karbamazepin & Rifampin & Karbamazepin seviyelerinde azalma \\
\hline Lityum & NSAİD Diüretikler & Lityum seviyelerinde artıl \\
\hline Oral kontraseptifler & Rifampin & Oral kontraseptif etkisinde azalma \\
\hline Oral Kontraseptifler & Antibiyotikler & Oral kontraseptif etkisinde azalma \\
\hline Oral Kontraseptifler & Troglitazon & Oral kontraseptif etkisinde azalma \\
\hline Sisaprid & $\begin{array}{l}\text { Eritromisin, Klaritromisin, Flukonazol, } \\
\text { Itrakonazol Ketokenazol, Nefazodon } \\
\text { Indinavir, Ritonavir }\end{array}$ & QT intervalinin uzaması \\
\hline Sisaprid & $\begin{array}{l}\text { 1A veya } 3 \mathrm{~A} \text { antiaritmikleri trisiklik } \\
\text { antidepresanlar fenotiazin }\end{array}$ & QT intervalinin uzaması \\
\hline Sildenafil & Nitratlar & Ciddi hipotansiyon \\
\hline Sildenafil & $\begin{array}{l}\text { Simetidin, Eritromisin } \\
\text { Itrakonzol, etokonazol }\end{array}$ & Sildenafil seviyelerinde artış \\
\hline $\begin{array}{l}\text { HMG-CoA redüktaz } \\
\text { inhibitörü }\end{array}$ & Niasin & Rabdomiyoliz \\
\hline Lovastatin & Varfarin & Varfarin etkisinde artış \\
\hline SSRI & Trisiklik antidepresanlar & $\begin{array}{l}\text { Trisiklik antidepresan } \\
\text { etkisinde artış }\end{array}$ \\
\hline SSRI & $\begin{array}{l}\text { Selegilin } \\
\text { Non-selektif MAO inhibitörleri }\end{array}$ & Hipertansif kriz \\
\hline SSRI & Tramadol & $\begin{array}{l}\text { Nöbet oluşum riskini artırır, Serotonin } \\
\text { sendromu }\end{array}$ \\
\hline SSRI & St. John's wort & Serotonin sendromu \\
\hline SSRI & $\begin{array}{lll}\text { Naratriptan, } & \text { Rizatriptan, } & \text { Sumatriptan, } \\
\text { Zolmatriptan } & & \end{array}$ & Serotonin sendromu \\
\hline
\end{tabular}

INR, Uluslararası Normalleştirilmiş Oran; NSAID, nonsteroidal anti-inflamatuar ilaç; HMG- CoA, HMG-KoA redüktaz (veya 3 hidroksi-3-metil-glutaril-KoA reduktaz inhibitörü; SSRI, seçici serotonin reuptake inhibitörü 
Tablo 4. En tehlikeli İlaç-İlaç Etkileşimleri. ${ }^{17}$

\begin{tabular}{|l|l|}
\hline Etkileşen İlaçlar & Potansiyel Etki \\
\hline $\begin{array}{l}\text { Varfarin + Nsai (Asetilsalisilik Asit, } \\
\text { Parasetamol, Metamizol Sodyum) }\end{array}$ & $\begin{array}{l}\text { Varfarinin etkisi artar, Kanamayı arttırır, } \\
\text { INR yi artırır }\end{array}$ \\
\hline Varfarin + Sülfonamid & $\begin{array}{l}\text { Varfarinin etkisi artar, Kanamayı arttırır, } \\
\text { INR yi artırır }\end{array}$ \\
\hline Varfarin + Makrolid Antibiyotikler & Varfarinin etkisi artar. \\
\hline Varfarin + Kinolon Grubu Antibiy.Ler) & Varfarinin etkisi artar. \\
\hline Varfarin + Fenitoin & Varfarinin etkisi artar. \\
\hline ACE inhibitörü + Potasyum Preparat1 & Hiperkalemi riski artar. \\
\hline ACE inhibitörü + Spironolakton & Hiperkalemi riski artar. \\
\hline Digoksin + Amiadoron & $\begin{array}{l}\text { Serum digoksin konsantrasyonları artar. Her iki ilaç da ilave bradikardik } \\
\text { etkilere sebep olabilir. Torsade de pointes, kardiyak aritmi bildirilmiştir. }\end{array}$ \\
\hline Digoksin + Verapamil & Serum digoksin konsantrasyonları artar. \\
\hline Teofilin + Kinolon Antibiyotik & Teofilin klerensini azaltarak plazma konsantrasyonunu artırır. 18 \\
\hline
\end{tabular}

ACE; Anjiyotensin Dönüştürücü Enzim 
Tablo 5. İlaç etkileşimi için elektronik medikal kayıtlar.

\begin{tabular}{|l|}
\hline www.mhc.com \\
\hline www.aafp.org \\
\hline www.herbmed.org \\
\hline www.lifebalm.com \\
\hline www.meds.queensu.ca \\
\hline uptodate \\
\hline lexicomp \\
\hline micromedex \\
\hline
\end{tabular}

